\title{
Salt-and-pepper-like retinopathy in a case of morning glory disc anomaly
}

\author{
Devesh Kumawat 이, ${ }^{1}$ Siddharth Patel, ${ }^{1}$ Anusha Sachan 자, ${ }^{2}$ Pranita Sahay $(1)^{3}$
}

${ }^{1}$ Ophthalmology, All India Institute of Medical Sciences, Rishikesh, India

${ }^{2}$ Ophthalmology, All India Institute of Medical Sciences, New Delhi, India

${ }^{3}$ Ophthalmology, Lady Hardinge Medical College, New Delhi, India

\section{Correspondence to} Dr Devesh Kumawat; deveshkumawat21@gmail.com

Accepted 13 January 2021

\section{DESCRIPTION}

A 9-year-old girl was brought by her parents for left eye inward deviation since infancy, associated with poor vision for the last few years. No ophthalmic consultation was done until due to financial constraints as per the parents. There were no systemic complaints. The child was born full term and had attained the developmental milestones as per her age.

On ocular examination, there was $30^{\circ}$ esotropia of the left eye on Hirschberg test. There was no evidence of microcornea or microphthalmos in either of the eyes. The visual acuity of right and left eye was 20/20 and light perception, respectively. Anterior segment examination was unremarkable with clear crystalline lens in both the eyes. On fundoscopic examination, the right eye

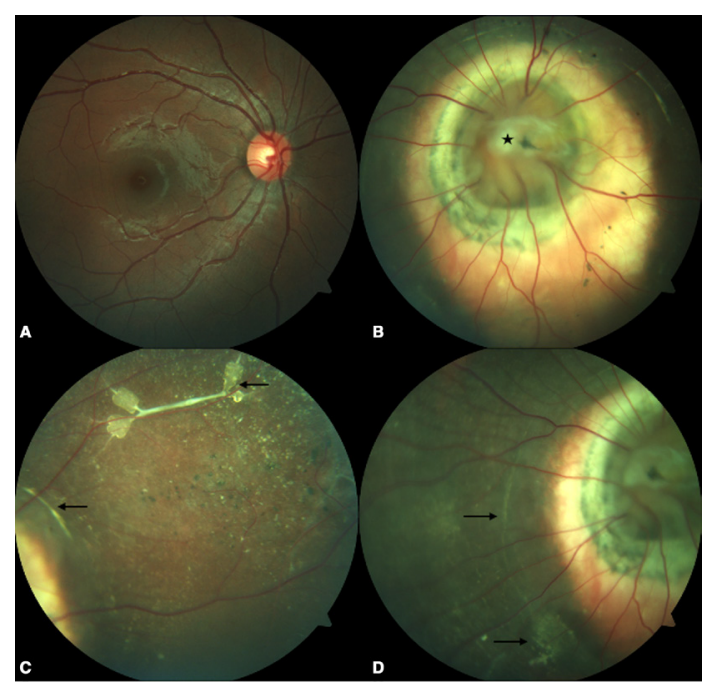

Figure 1 Fundus photographs of a 9-year-old girl. (A) Right eye photograph shows a normal size healthy optic disc with a cup and neuroretinal rim, normal branching retinal vessels, and an attached unremarkable retina. (B) Left eye photograph shows a large excavated disc, cup filled with greyish glial tissue (black asterix), radially emanating straight numerous vessels with no distinction of arteries and veins, peripapillary pigmentation with severe chorioretinal atrophy and scleral show outside of the pigmentation, and shallow retinal detachment in the peripapillary area. (C) Superotemporal quadrant photograph shows multiple punctate areas of hypo and hyperpigmentation suggestive of salt-and-pepper retinopathy. Subretinal gliosis in the form of linear bands is also seen (black arrows). (D) Subretinal gliosis is also seen nasal to the optic disc (black arrows). In-between the disc margin and the gliosis, the retinal detachment can be appreciated. had an average size healthy optic disc, normal retinal vascular pattern and unremarkable retina (figure 1A). The left eye fundus (figure 1B) had a large excavated disc with peripapillary chorioretinal atrophy. Multiple anomalous vessels were seen emanating and radiating from the disc with a tuft of greyish-black tissue in the centre filling the cup. It was difficult to differentiate between the arterial and venous nature of these vessels.

Diffuse granular pigmentation was noted in the mid and far periphery with stippled hypopigmentation and hyperpigmentation suggestive of saltand-pepper retinopathy (figure 1C). On careful examination, a retinal detachment (RD) was noted in the peripapillary area (figure 1b). Subretinal gliosis was also noted in few areas, with subretinal band in the superotemporal quadrant (figure 1C) and around the disc (figure 1C,D). On systemic examination, the patient had no mid-line facial and oral abnormalities, no hearing deficits and normal intelligence.

A diagnosis of morning glory disc anomaly (MGDA) with pigmentary retinopathy secondary to spontaneously resolving $\mathrm{RD}$ was made. In view of longstanding strabismus and RD, guarded visual prognosis was explained and cosmetic surgical correction of the strabismus was discussed with the parents. A neurological consultation and central nervous system (CNS) imaging was advised, but the parents did not follow up.

MGDA is a typically a unilateral congenital optic disc excavation with resemblance to the morning glory flower. ${ }^{1}$ Serous RD occurs in one-third of the cases. ${ }^{12}$ Serous RD develops from leakage of cerebrospinal fluid from the perineural space into the subretinal space or from seepage of degenerated vitreous through small peripapillary retinal breaks arising due to contractile glial tissue. ${ }^{12}$ The serous detachments are usually shallow and occasionally resolves spontaneously over time. ${ }^{12}$ Spontaneous reattachment of RD is not an uncommon entity. $^{34}$ Spontaneous reattachment gives rise to retinal pigment epithelium clumping and subretinal deposits, sometimes giving an appearance of pseudoretinitis pigmentosa or salt-and-pepper retinopathy. ${ }^{45}$ Other causes such as congenital rubella, congenital syphilis, intraocular foreign body and drug toxicity should be ruled out in cases of pigmentary retinopathy. ${ }^{5}$ However, in the current case, the presence of MGDA, shallow peripapillary detachment and subretinal gliosis, all pointed towards a spontaneously resolving RD. The visual prognosis is affected not only by the congenital optic nerve defect, but also by associated strabismus and serous 
RD. ${ }^{1}$ MGDA may be associated with mid-facial malformations and transsphenoidal basal encephalocele; therefore, a general examination and CNS imaging is always advised. ${ }^{1}$

\section{Learning points}

- Morning glory disc anomaly is commonly associated with shallow serous retinal detachment.

- Retinal detachment may resolve spontaneously and lead to salt-and-pepper-like retinopathy.

- Visual prognosis depends on the congenital optic nerve defect and the associated strabismus and retinal detachment.

Twitter Anusha Sachan @Anusha Sachan

Contributors DK: Concept and design, acquisition of data, interpretation of data, revision of the work. SP: Interpretation of data, drafting of work. AS: Acquisition of data, interpretation of data, drafting of work. PS: Concept and design, interpretation of data, revision of the work. All authors approved the work and take responsibility of the submission.
Funding The authors have not declared a specific grant for this research from any funding agency in the public, commercial or not-for-profit sectors.

Competing interests None declared.

Patient consent for publication Parental/guardian consent obtained.

Provenance and peer review Not commissioned; externally peer reviewed.

\section{ORCID iDs}

Devesh Kumawat http://orcid.org/0000-0003-0204-7024

Anusha Sachan http://orcid.org/0000-0001-9737-6706

Pranita Sahay http://orcid.org/0000-0002-3325-4192

\section{REFERENCES}

1 Lee BJ, Traboulsi El. Update on the morning glory disc anomaly. Ophthalmic Genet 2008;29:47-52.

2 Chang S, Gregory-Roberts E, Chen R. Retinal detachment associated with optic disc colobomas and morning glory syndrome. Eye 2012;26:494-500.

3 Chung SE, Kang SW, Yi C-H. A developmental mechanism of spontaneous reattachment in rhegmatogenous retinal detachment. Korean J Ophthalmol 2012;26:135-8.

$4 \mathrm{Cho} \mathrm{HY}$, Chung SE, Kim Jl, et al. Spontaneous reattachment of rhegmatogenous retinal detachment. Ophthalmology 2007;114:581-6.

5 Hamel C. Retinitis pigmentosa. Orphanet J Rare Dis 2006;1:40.

Copyright 2021 BMJ Publishing Group. All rights reserved. For permission to reuse any of this content visit

https://www.bmj.com/company/products-services/rights-and-licensing/permissions/

BMJ Case Report Fellows may re-use this article for personal use and teaching without any further permission.

Become a Fellow of BMJ Case Reports today and you can:

- Submit as many cases as you like

- Enjoy fast sympathetic peer review and rapid publication of accepted articles

- Access all the published articles

- Re-use any of the published material for personal use and teaching without further permission

Customer Service

If you have any further queries about your subscription, please contact our customer services team on +44 (0) 2071111105 or via email at support@bmj.com.

Visit casereports.bmj.com for more articles like this and to become a Fellow 